\title{
Response Guidelines for Newborn Infants Born to Mothers with Suspected or Confirmed Coronavirus Disease 2019
}

Do-Hyun Kim, MD, PhD

Department of Pediatrics, Dongguk University Ilsan Hospital, Goyang, Korea

\section{ABSTRACT}

Since December 2019, the coronavirus disease 2019 (COVID-19) has been spreading rapidly worldwide. With the increase in the number of infections, the numbers of pregnant women and newborn infants with COVID-19 are also increasing. According to the limited recent studies, COVID-19 appears to be mainly transmitted to newborn infants by the mother's droplets or direct contact with the mother, and no clear evidence supports the vertical transmission from the mother to the newborn infant. To date, the likelihood of severe outcomes in newborn infants born to mothers with confirmed COVID-19 is relatively very low, but the possibility should be considered. The present response guidelines address the management of newborn infants born to mothers with suspected or confirmed COVID-19. The management covers precautions for birth attendants or medical staffs, testing for COVID-19, isolation, neonatal care, breastfeeding, and mother/baby contact. These response guidelines can be revised in accordance with further updates on COVID-19 and should be adapted to each local health-care facility.

Key Words: Coronavirus; COVID-19; Pregnant women; Infant, newborn; Guideline

\section{서론}

2019년 12월 이후 코로나바이러스감염증-19 (coronavirus disease 2019, COVID-19)는 전 세 계적으로 급속도로 퍼지고 있으며 소아청소년 및 임산부와 신생아 감염도 증가하고 있다. 소아 청소년의 발생 빈도는 성인에 비해 상대적으로 매우 적고 질환의 중증도 또한 경미하다고 알려 져 있으며, 신생아 또한 이와 크게 다르지 않다 ${ }^{1-3)}$. 2020년 4월 1일 미국에서 생후 6주 된 영아가 COVID-19에 감염되어 사망하였다고 보도되었으나 저자가 알기에 아직 신생아 사망은 보고된 바 없다. 최근까지의 국내 상황을 보면, 2020년 3월 8일 국내 최연소 COVID-19 환자로 확진된 생후 27 일 된 신생아는 아주 양호한 상태로 3월 27일 퇴원하였다. 또 3월 12 일까지의 언론 보도 를 종합하면 총 9명의 임산부가 확진되었고, 3 월 6일 확진 산모로부터 출생한 여아(만삭아, 정상 체중)는 음성 판정을 받고 건강하게 퇴원하였다.

현재까지의 연구 결과에 따르면, COVID-19는 산모의 비말이나 산모와의 직접 접촉에 의해 신생아에게 주로 전파되는 것으로 보이며, 산모로부터 신생아에게 수직 감염으로 전파된다는
Received: 27 April 2020

Accepted: 12 May 2020

Correspondence to: Do-Hyun Kim, $\mathrm{MD}, \mathrm{PhD}$

Department of Pediatrics, Dongguk University Ilsan Hospital, 27 Donggukro, Ilsandong-gu, Goyang 10326, Korea Tel: +82-31-961-7184

Fax: +82-31-961-7182

E-mail: dayeong1@hanmail.net

Copyright(c)

By Korean Society of Neonatology.

All right reserved.

This is an Open-Access article distributed under the terms of the Creative Commons At tribution Non-Commercial License (http:// creativecommons.org/licenses/by-nc/4.0), which permits unrestricted non-commercial use, distribution, and reproduction in any medium, provided the original work is pro perly cited. 
증거는 없다. 분만 전후 다른 경로를 통해 신생아에게 전파될 수 있 는지의 여부도 아직 알려져 있지 않다 ${ }^{1-3}$. 같은 코로나바이러스 감 염증인 중증급성호흡기증후군(severe acute respiratory syndrome, SARS)과 중동호흡기증후군(Middle East respiratory syndrome, MERS)의 유행 시에도 산모-태아 간에 코로나바이러스의 자궁 내 또 는 경태반 감염의 보고는 없었고 ${ }^{2,3}$, , 2020년 1월 우한시 Zhongnan 병원에서 COVID-19 확진 산모 9명으로부터 출생한 신생아의 제대 혈과 인후부, 산모의 양수와 모유 등에서 전혀 바이러스가 검출되지 않았닥. 다만, Zeng 등ㄱ은 COVID-19 폐렴을 보이는 산모로부터 출생한 33명의 신생아를 대상으로 한 코호트 연구에서 3명의 신생 아가 조기 발현 COVID-19로 진단되어 수직 감염의 가능성을 완전 히 배제할 수 없다고 주장하여 추가적인 연구가 필요하다.

COVID-19 확진 산모의 신생아에서 조산 등의 합병증이 보고된 바 있으나 그 인과 관계는 불확실하다 2,3). 확진 산모로부터 출생한 신생아에게 심각한 위험이 있다는 보고는 없지만, 2003년 SARS 유 행 시 SARS 감염 산모의 태아 합병증(조산 $44 \%$, 자궁 내 발육지연 $<12 \%$, 태아 사망 <3\%, 신생아 사망 $12 \%$ )이 높았던 것을 고려할 때 중증화될 가능성을 배제할 수 없다 ${ }^{6}$. 또한 주산기 또는 신생아 진료 의 특수성을 고려할 때, COVID-19 의심 또는 확진 산모로부터 출생 한 신생아에 대한 COVID-19 대응 지침이 시급히 필요하다.

본 종설은 2020년 4월 14일 대한신생아학회 감염위원회에서 작 성하여 회원들에게 배포한 '코로나바이러스감염증-19 (COVID-19) 신생아 대응 지침(제4판)'을 수정, 보완한 것이다. 최근에 발표된 여러 지침들과 연구 결과들을 기반으로 COVID-19 의심 또는 확진 산모로부터 출생한 신생아에 대한 대응 방안을 중심으로 기술하였 다. 보다 구체적으로 산모 내원 시 대처, 분만 시 대처, 감염 관리, COVID-19 확진 검사, 신생아 관리, 격리 방법과 기간, 신생아 관리, 모유 수유, 산모와 신생아 접촉 등에 대해 살펴보고자 하였다.
개요

본 지침에서 COVID-19 사례 정의는 2020년 3월 2일 개정된 '중앙 방역대책본부 코로나바이러스감염증-19 대응 지침 제7판’을 기반으 로 하였고(Table 1$)^{7}$, 출생 후 신생아 COVID-19 검사와 격리 해제 기준은 2020년 3월 20일 배포된 '대한소아감염학회 코로나바이러 스감염증-19 대응 지침(신생아, 영아, 소아청소년)'을 기반으로 하 였다 ${ }^{1 .}$. 산모와 신생아 관리에 관한 전반적인 사항은 한국질병관리 본부 ${ }^{7}$, 대한소아감염학회 ${ }^{1}$, 미국질병통제예방센터 ${ }^{8)}$, 미국소아과학 회" 지침을 주로 참고하였다. Figure 1은 '대한소아감염학회 코로나 바이러스감염증-19 대응 지침(신생아, 영아, 소아청소년)'에서 인용 한 COVID-19 의심 또는 확진 산모로부터 출생한 신생아 관리에 대 한 모식도이다 ${ }^{11}$.

\section{산모 내원 시 대처}

COVID-19 의심 또는 확진 산모가 내원하게 되면 산부인과 의사 에게 사전에 통보하여 가장 적절한 분만 장소를 선정하고, 감염관 리용품 및 개인보호장구(personal protective equipment, PPE) 등을 올바르게 배치하는 등 적절한 감염 관리 대비를 해야 한다. 또한 분 만 이후 신생아 관리에 대한 계획도 미리 수립해야 한다 ${ }^{1,8)}$.

\section{COVID-19 확진 산모 내원 시}

유선으로 내원 문의가 오는 경우에는 1339 또는 관할 보건소로 연 락하여 국가지정 음압 입원치료병상을 배정받도록 하는 것이 원칙 이다. 국가지정병원으로 내원 시 격리 전용병동 또는 미리 결정된 전용병동(음압격리실 1 인실로 구성)에 입원한다. 이송 연락 후 부득 이하게 국가지정병원이 아닌 병원으로 내원해야 하는 경우에는 바 로 병원 내 지정 격리장소에서 대기한 후, 즉시 배정된 국가지정 음

Table 1. Case Definition of COVID-19

\section{[확진환자]}

1) 임상증상에 관계없이 진단을 위한 검사기준에 따라 감염병 병원체 감염이 확인된 자

※ 진단검사: 코로나바이러스감염증-19 유전자(PCR) 검사, 바이러스 분리

[의사환자]

1) 확진환자의 증상발생 기간 중 확진환자와 접촉한 후 14 일 이내에 발열( $37.5^{\circ} \mathrm{C}$ 이상) 또는 호흡기증상(기침, 호흡곤란, 인후통 등)이 나타난 자 [조사대상 유증상자]

1) 의사의 소견에 따라 원인미상폐렴 등 코로나19가 의심되는 자

2) 중국(홍콩, 마카오 포함) 등 코로나바이러스감염증-19 지역 전파(*)가 있는 국가를 방문한 후 14 일 이내에 발열( $37.5^{\circ} \mathrm{C}$ 이상) 또는 호흡기증상(기침, 호흡곤란 등)이 나타난 자

*WHO 홈페이지 또는 질병관리본부 홈페이지 참조

$3)$ 코로나바이러스감염증-19 국내 집단발생과 역학적 연관성이 있으며, 14 일 이내에 발열( $37.5^{\circ} \mathrm{C}$ 이상) 또는 호흡기증상(기침, 호흡곤란 등)이 나타난 자 


\section{코로나바이러스감염증-19(코로나19) 확진 또는 의심 환자로부터} 출생한 신생아 관리
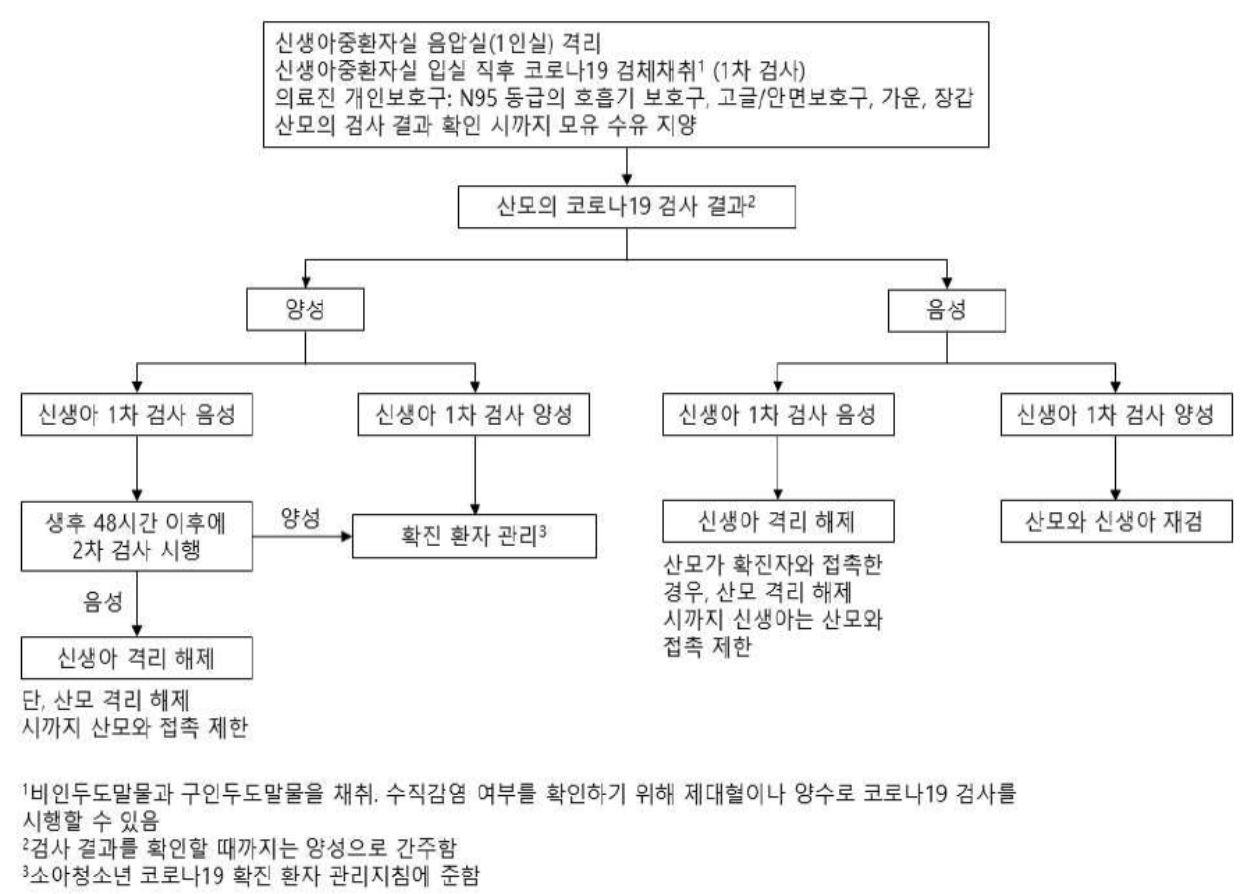

Figure 1. Flow chart of care for newborn Infants born to mothers with suspected or confirmed COVID-19. Adapted from The Korean Society of Pediatric Infectious Diseases ${ }^{1)}$.

압 입원치료병상으로 이송한다. 즉시 이송이 불가능한 경우에는 이 송하기 전까지 응급실 내 또는 병원 내 지정 음압격리실에서 대기하 고, 이송 전 진료가 필요한 경우에는 대기 중인 음압격리실에서 태 아 모니터 및 초음파검사를 시행한다. 국가지정병원 사정 또는 산모 나 태아 상태가 위급하여 전원이 불가한 경우에는 병원 내 음압격리 실에서 입원 치료한다. 산모 격리 장소의 우선순위는 각 병원의 세 부 지침에 따른다. 의료진 혹은 이송요원은 레벨 $\mathrm{D}$ 보호구(레벨 D 전신보호복 및 N95 마스크)를 착용하고, 산모 환자는 호흡곤란이 없 고 상태가 양호하면 가능한 한 KF94 등급 이상의 마스크를 착용한 다. 확진 산모가 병원 내에서 이동 시 다른 환자나 의료진이 노출되 지 않도록 이동 경로를 미리 계획하여 확보해야 한다 ${ }^{1,6-8,10-15)}$.

\section{2. 의사환자/조사대상 유증상자 산모 내원 시}

마찬가지로 유선으로 내원 문의가 오는 경우에는 1339 또는 관할 보건소로 연락하여 국가지정 음압 입원치료병상을 배정받도록 하 는 것이 원칙이다. 응급실에 바로 내원한 경우 응급실 내의 음압격 리실 또는 전용 병동 음압격리실로 이송하여 COVID-19 확진 검사 를 시행한다. 산모는 호흡곤란이 없고 상태가 양호하면 가능한 한 KF94 등급 이상의 마스크를 착용한다. 검사 결과가 나오기 전에 진 료가 필요한 경우에는 병원 내 지정 음압격리실에서 태아 모니터 및 초음파 검사를 시행한다. 음압격리실이 불가능한 경우에는 환기가
가능한 별도의 격리실에서 검사를 시행한다. 산모의 격리 장소의 우 선 순위는 각 병원의 세부 지침에 따른다. 확진 검사 결과가 나오기 전에는 확진 확자에 준하여 감염관리를 적용하고, 확진 검사 결과 가 양성이면 확진 산모 내원 시 관리 지침에 준하여 대처한다. 의료 진 혹은 이송요원은 레벨 D 보호구 착용을 권장하나 불가능한 경우 에는 4종 보호구(KF94 또는 동급의 호흡기보호구, 일회용 장갑, 일 회용 긴팔가운 또는 전신보호복, 고글 또는 안면보호구)를 착용한 다. 단, 에어로졸이 발생하는 시술 시에는 레벨 D 보호구를 착용한 다. 확진 검사 결과가 음성인 경우, 잠복기에 해당되는 기간 동안 별 도의 격리된 공간(1인실)에 입원하고 격리 기간 동안 증상 발생 시 즉시 추가 확진 검사를 시행한다. 산모 격리 기간 동안 의료진은 4 종 보호구 이상의 보호구를 착용한다 ${ }^{1,6-8,10-15)}$.

\section{분만 시 대처}

COVID-19 의심 또는 확진 산모의 분만은 산부인과, 소아청소년 과 의사에게 미리 통보한 후 적절한 감염 관리 및 신생아 관리에 대 한 계획을 수립해야 한다 ${ }^{1)}$. 세계산부인과초음파학회 지침에 따르면 COVID-19 의심 또는 확진 산모는 가능한 음압격리실에서 분만해야 한다. COVID-19 결과가 나올 때까지 의심 산모는 확진 환자에 준하 
여 처치해야 한다 ${ }^{16)}$.

\section{COVID-19 확진 산모 분만 시}

자연분만 시에는 음압격리실 또는 음압수술실에서, 제왕절개 시 에는 음압수술실에서 분만을 시행한다. 분만을 위해 이동 시 산모 는 가능하면 수술용 마스크를 착용하며 다른 환자나 의료진이 노출 되지 않는 이동 경로를 미리 계획하여 확보한다. 산모로부터의 바 이러스 에어로졸 발생 가능성 및 에어로졸을 생성할 수 있는 신생 아 소생술 가능성 때문에 분만에 참여하는 의료진과 이송요원은 모 두 레벨 D 보호구를 착용하며, 착용이 불가능한 경우에는 N95 마스 크, 장갑, 전신보호복(또는 방수성 긴팔가운), 고글 등을 착용한다. 주산기 감염을 줄이기 위해 가능하면 탯줄을 조기 차단하고(early clamping), 산모 혈액과 양수를 최대한 빨리 신생아 몸에서 제거한 다(early cleaning). 시술 시 가능하면 일회용 기구나 물품을 사용한 다 $1,6-9,13-15)$.

\section{2. 의사환자/조사대상 유증상자 산모 확진 검사 확인 전 분만 시}

확진 산모 분만 시 관리 지침에 준하여 대처한다. 분만 후 확진 결 과 양성이면 확진 환자에 준하여 진료하고, 확진 결과 음성이면 잠 복기에 해당되는 기간 동안 별도의 격리된 공간에 입원하고 격리 기 간 동안 증상 발생 시 즉시 추가 확진 검사를 시행한다 ${ }^{1,6-9,13-15)}$.

\section{출생 후 신생아 관리}

분만 시점에 COVID-19 의심 또는 확진 산모에게서 태어난 신생 아는 COVID-19 검사결과를 확인하기 전까지 의심환자로 간주해야 한다. 의심환자로 간주되는 신생아는 우선 다른 건강한 신생아로부 터 격리해야 한다 ${ }^{1,8)}$. 분만 후 신생아는 분만장 또는 수술장에서 음 압격리실까지 이송용 인큐베이터(transport incubator)를 사용하여 이송하며 가능한 노출이 적은 경로를 계획하여 동선을 통제하며 이 동한다 ${ }^{1)}$.

\section{COVID-19 확진 산모의 신생아}

1) 신생아 COVID-19 스크리닝 검사

COVID-19 확진 검사는 입원 직후 비인두와 구인두 도말물을 채 취하여 시행한다. 참고로 자궁 내 감염을 확인하기 위해 분만장이 나 수술장에서 태반, 제대혈 또는 양수를 확보하여 COVID-19 검사 를 시행할 수 있다 ${ }^{1,7-9)}$.

\section{2) 격리 기간 및 해제}

출생 당시 검사가 음성이면 생후 48시간 이후에 2차 검사를 시행 하여 두 번 모두 음성이면 최종 음성으로 격리 해제한다. 단, 의료진
의 판단에 따라 산모의 증상이 심하여 출생 시 호흡기 감염이 가능 할 때는 출생 후 2 주간 격리할 수 있다. 2 차 검사 후 격리 해제가 되 더라도 의료진의 판단에 따라 병원 격리실에서 일정 기간 관찰할 수 있다(대한소아감염학회 지침 ${ }^{1)}$ 에는 본 추가 격리 사항 없음. 대한신 생아학회 감염위원회 자체 의견임). 정해진 확진 검사 외에도 증상 발생 시 즉시 확진 검사를 시행한다. 확진 검사가 양성이면 소아청 소년 확진 환자 관리지침에 준하여 관리한다. COVID-19 양성인 유 증상 신생아의 격리 해제는 임상적으로 호전(발열 소실: 48시간 이 상 체온 $37.5^{\circ} \mathrm{C}$ 미만)되고 호흡기 증상의 호전이 뚜렷하면서(처음부 터 열없이 증상이 경미한 경우였다면 나빠지지 않았거나 더 좋아질 경우), polymerase chain reaction (PCR) 검사 결과가 24시간 이상 간격으로 2회 음성인 경우에 이루어진다. COVID-19 양성인 무증상 신생아는 최소 1 주일 이후에 PCR 검사 결과가 24 시간 이상 간격으 로 2회 음성인 경우 격리 해제된다 ${ }^{1,7-9)}$.

\section{3) 정상 신생아의 관리}

출생 후 병원 내 지정된 음압격리실로 이동한다. 음압격리실이 불 가능한 경우에는 미리 지정된 환기가 가능한 별도로 마련된 격리실 로 이동하여 COVID-19 관련 증상의 발생 여부를 면밀히 관찰한다. 신생아 격리 장소의 우선 순위는 각 병원의 세부 지침에 따른다. 출 생 후 신생아는 피부 표면에 존재할 지도 모르는 바이러스를 제거하 기 위해 목욕을 하고, 산모가 완치될 때까지 산모와 접촉하지 않는 다. 의료인의 복장은 4 종 보호구 이상을 권장한다. 격리 해제는 2) 에 준한다 ${ }^{1,7-12)}$.

4) 신생아중환자실 치료가 필요한 신생아 관리

출생 후 신생아중환자실 내 전실이 있는 음압격리실로 이동한다. 전실이 있는 음압격리실이 불가능하면 전실이 없는 음압격리실로, 전실이 없는 음압격리실이 불가능하면 신생아중환자실 내 격리실 로 이동한다. 신생아 격리 장소의 우선 순위는 각 병원의 세부 지침 에 따른다. 출생 후 신생아는 피부 표면에 존재할 지도 모르는 바이 러스를 제거하기 위해 목욕을 하고, 산모가 완치될 때까지 산모와 접촉하지 않는다. 의료진의 복장은 마찬가지로 4 종 보호구 이상을 권장하며, 에어로졸이 발생하는 시술 또는 심폐소생술을 시행할 때 는 레벨 D 보호구를 착용한다. 격리 해제는 2)에 준한다 ${ }^{1,7-12)}$.

\section{2. 의사환자/조사대상 유증상자 산모가 확진 검사 음성이나 잠 복기 내인 경우}

1) 신생아 COVID-19 스크리닝 검사

확진 산모의 신생아와 마찬가지로 출생 당일 입원 직후 비인두 와 구인두 도말물을 채취하여 COVID-19 확진 검사를 시행한다 ${ }^{1,7-9)}$. 


\section{2) 격리 기간 및 해제}

신생아는 검사 결과가 나오기 전까지 격리하고, 검사 결과가 음성 인 경우 바로 격리 해제한다. 신생아의 검사 결과가 양성인 경우 산 모와 신생아 모두 재검사하여 다시 결정한다. 신생아의 검사 결과가 최종 음성이며 다른 이유로 입원이 필요하지 않으면 가능한 빨리 퇴 원 조치한다 ${ }^{1,7-9)}$.

\section{3) 정상 신생아의 관리}

출생 후 최종 음성 판정 전까지 병원 내 별도의 격리 공간에서 격 리한다. 산모가 밀접접촉자라면 산모의 격리가 해제될 때까지 신생 아와의 접촉을 제한한다. 격리 중 의료진의 복장은 4 종 보호구 이상 의 보호구를 권장한다. 격리 해제는 2)에 준한다 ${ }^{1,7-9)}$.

\section{4) 신생아중환자실 치료가 필요한 신생아 관리}

산모의 잠복기에 해당하는 기간 내라면 돌봄이 필요한 기간 동안 신생아중환자실 내 격리실에 격리한다. 신생아 격리 장소의 우선순 위는 각 병원의 세부 지침에 따른다. 산모가 밀접접촉자라면 산모 의 격리가 해제될 때까지 신생아와의 접촉을 제한한다. 의료진의 복 장은 4종 보호구 이상의 보호구를 권장한다. 격리해제는 2)에 준한 다 ${ }^{1,7-12)}$.

\section{모유수유}

서론에서 언급한 Chen 등 ${ }^{4}$ 의 연구에서, COVID-19 폐렴으로 진 단된 9명의 산모의 모유에서 severe acute respiratory syndrome coronavirus 2 (SARS-CoV-2) quantitative RT-PCR은 모두 음성이었 다. 현재까지 모유를 통한 COVID-19감염은 알려진 바 없고, 모유수 유 시 바이러스 전파는 비말이나 접촉에 의한 것으로 생각된다. 미 국질병통제예방센텅ㅇㅇㅘ 미국소아과학회ํ는 모유수유를 금지하고 있지는 않으며, 의심 또는 확진 산모의 경우 손 씻기, 안면마스크 착 용 등 바이러스 전파를 막기 위한 철저한 주의 조치를 한 후 모유수 유하기를 권장한다. 하지만, 대한소아감염학회 ${ }^{1)}$ 는 모유수유에 대 한 근거가 부족하므로 확진 환자로부터 출생하였거나 아직 임산부 의 바이러스 검사 결과를 모르는 경우에는 모유수유는 지양하며, 임 산부의 COVID-19 검사 결과가 음성으로 확인된 뒤 모유수유를 하 기를 권장한다. 이때, 산모와 신생아가 격리 중이라면 직접 수유는 지양하고 모유를 유축하여 수유하도록 하며, 냉동 보관한 후 녹여서 수유할 수 있다 ${ }^{1)}$. 유축기를 사용할 때는 유축기와 병을 만지기 전에 손 씻기 등을 철저히 하고, 유축 후 유축기의 모든 부분을 철저히 세 척 및 소독해야 한다 ${ }^{8)}$. 만약 COVID-19 의심 또는 확진 산모가 직접 수유를 강력히 원한다면 마스크 착용 및 손 씻기 등 개인 위생을 엄 격하게 준수해야 한다 ${ }^{1,8,9)}$.

\section{산모와 신생아 접촉}

미국질병예방통제센터 ${ }^{8}$ 에 따르면 산모와 신생아 간의 전파를 막 기 위해 산모가 격리되어 있을 때는 일시적으로 산모와 신생아를 분 리한다. 분리된 신생아는 건강한 부모와 돌봄 종사자를 제외하고 는 방문객을 제한한다. 이때, 방문객 복장은 4종 보호구를 권장한 다. 부득이하게 분리하지 않고 모자동실을 하게 된다면 신생아의 COVID-19 노출을 최소화할 수 있도록 커튼과 같은 물리적 경계물 (barrier)을 설치하고 산모와 신생아 간 $2 \mathrm{~m}$ 이상의 거리를 유지한 다. 수유 시에는 반드시 마스크를 하고 매 수유 시마다 손 씻기를 철 저히 수행해야 한다 ${ }^{1,8,9)}$.

\section{결론}

본 종설의 COVID-19 대응 지침은 COVID-19 의심 또는 확진 산 모로부터 출생한 신생아에 대한 전반적인 대응 방안을 우리나라 의 실정에 맞게 제시하고 있다. 기존에 보지 못했던 세계적 유행성 (pandemic) 질환인 COVID-19에 관한 새로운 연구 결과가 신속하고 광범위하게 발표되고 있으므로, 이러한 새로운 연구 결과와 함께 유 행 상황, 정부 방침의 변화 등에 따라 본 지침은 수정될 수 있다. 본 대응 지침은 비교적 일반적인 상황을 다루고 있으므로 실제 임상에 서 적용되려면 본 지침을 참고로 각 센터의 상황에 맞는 개별적인 내부 지침에 따라 보다 세부적이고 정밀하게 대응해야 할 것이다.

\section{ARTICLE INFORMATION}

\section{Ethical statement}

None

\section{Conflicts of interest}

No potential conflict of interest relevant to this article was reported.

\section{Author contributions}

Conception or design: D.H.K.

Acquisition, analysis, or interpretation of data: D.H.K.

Drafting the work or revising: D.H.K.

Final approval of the manuscript: D.H.K.

\section{ORCID}

Do-Hyun Kim https://orcid.org/0000-0002-5003-8475 


\section{Acknowledgments}

None

\section{REFERENCES}

1. The Korean Society of Pediatric Infectious Diseases. COVID-19 response guidelines (newborn, infant, child and adolescent) [Internet]. Seoul: The Korean Society of Pediatric Infectious Diseases; 2020 [cited 2020 May 16]. Available from: http://www. kspid.or.kr/.

2. Schwartz DA. An analysis of 38 pregnant women with COVID19 , their newborn infants, and maternal-fetal transmission of SARS-CoV-2: maternal coronavirus infections and pregnancy outcomes. Arch Pathol Lab Med 2020 Mar 17 [Epub]. https:// doi.org/10.5858/arpa.2020-0901-SA.

3. Schwartz DA, Graham AL. Potential maternal and infant outcomes from (Wuhan) coronavirus 2019-nCoV infecting preg. nant women: lessons from SARS, MERS, and other human coronavirus infections. Viruses 2020;12:194.

4. Chen H, Guo J, Wang C, Luo F, Yu X, Zhang W, et al. Clinical characteristics and intrauterine vertical transmission potential of COVID-19 infection in nine pregnant women: a retrospective review of medical records. Lancet 2020;395:809-15.

5. Zeng L, Xia S, Yuan W, Yan K, Xiao F, Shao J, et al. Neonatal early-onset infection with SARS-CoV-2 in 33 neonates born to mothers with COVID-19 in Wuhan, China. JAMA Pediatr 2020: e200878.

6. Maxwell C, McGeer A, Tai KFY, Sermer M. No. 225: Management guidelines for obstetric patients and neonates born to mothers with suspected or probable severe acute respiratory syndrome (SARS). J Obstet Gynaecol Can 2017;39:e130-7.

7. Korea Center for Disease Control and Prevention. Coronavirus disease (COVID-19) response guidelines 7th edition [Internet]. Sejong: Ministry of Health and Welfare; 2020 [cited 2020 May 16]. Available from: http://ncov.mohw.go.kr/.

8. Centers for Disease Control and Prevention. Coronavirus disease 2019 (COVID-19): considerations for inpatient obstetric healthcare settings [Internet]. Atlanta: CDC; 2020 [cited 2020 May 16]. Available from: https://www.cdc.gov/coronavirus/ 2019-ncov/hcp/inpatient-obstetric-healthcare-guidance. html.

9. American Academy of Pediatrics. AAP issues guidance on infants born to mothers with suspected or confirmed COVID19 [Internet]. Itasca: AAP; 2020 [cited May 16]. Available from: https://www.aappublications.org/news/2020/04/02/infantcovidguidance040220.

10. Provincial Infectious Diseases Advisory Committee (PIDAC). Best practice for infection prevention and control in perinatology: in all health care settings that provide obstetrical and newborn care [Internet]. Toronto: Public Health Ontario; c2020 [cited 2020 Apr 1]. Available from: https://www.publicheal thontario.ca/-/media/documents/bp-ipac-perinatology.pdf ?la=en.

11. Bryant K. Healthcare-associated infections in newborn nurseries and neonatal intensive care units. In: Glen MC, editor. Hospital epidemiology and infection control. 4th ed. Philadelphia: Lippincott Williams \& Wilkins, 2012:738-56.

12. RPA Newborn Care Infection QI subcommittee and adapted material from the Provincial Infectious Diseases Advisory Committee Ontario. Women and babies: infection prevention and control in NICU [Internet]. Camperdown: NSW Government; 2015 [cited 2020 May 16]. Available from: https://www.slhd. nsw.gov.au/rpa/neonatal\%5Ccontent/pdf/guidelines/Inf ectionControlGuidelineMar2015.pdf.

13. Lee SJ, Na S. Recent trend about pregnant women with suspect ed or confirmed coronavirus disease 2019 (COVID-19) infection. Perinatology 2020;31:1-6.

14. Rasmussen SA, Smulian JC, Lednicky JA, Wen TS, Jamieson DJ. Coronavirus disease 2019 (COVID-19) and pregnancy: what obstetricians need to know. Am J Obstet Gynecol 2020;222:41526.

15. Favre G, Pomar L, Qi X, Nielsen-Saines K, Musso D, Baud D. Guidelines for pregnant women with suspected SARS-CoV-2 infection. Lancet Infect Dis 2020 Mar 3 [Epub]. https://doi. org/10.1016/S1473-3099(20)30157-2.

16. Poon LC, Yang H, Lee JCS, Copel JA, Leung TY, Zhang Y, et al. ISUOG Interim Guidance on 2019 novel coronavirus infection during pregnancy and puerperium: information for healthcare professionals. Ultrasound Obstet Gynecol 2020;55:700-8. 